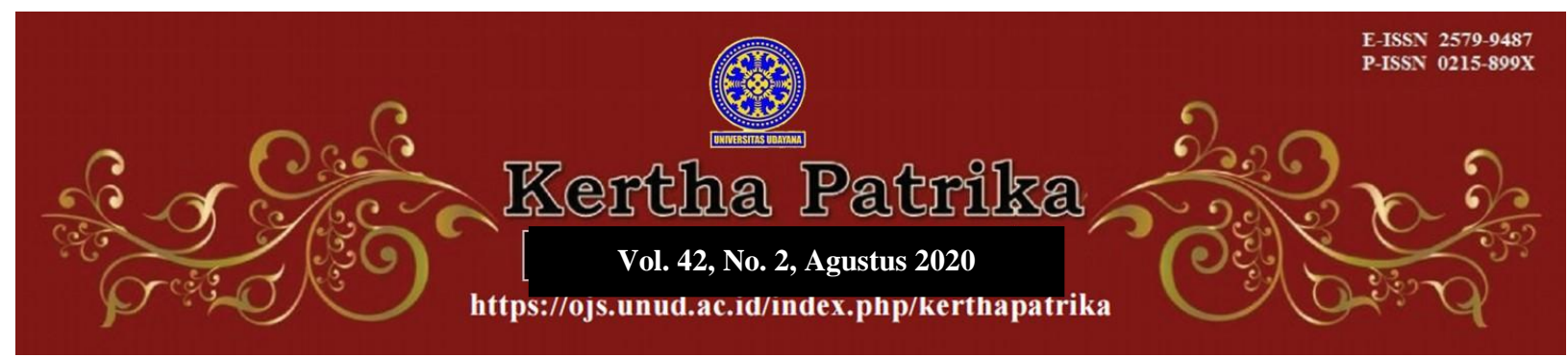

\title{
Crime Victims Protection in Indonesia: An Analysis of the Recent Victim Protection Acts
}

\author{
Mahfud ${ }^{1}$ \\ ${ }^{1}$ Faculty of Law Syiah Kuala University, \\ E-mail: mahfud_jufri@unsyiah.ac.id
}

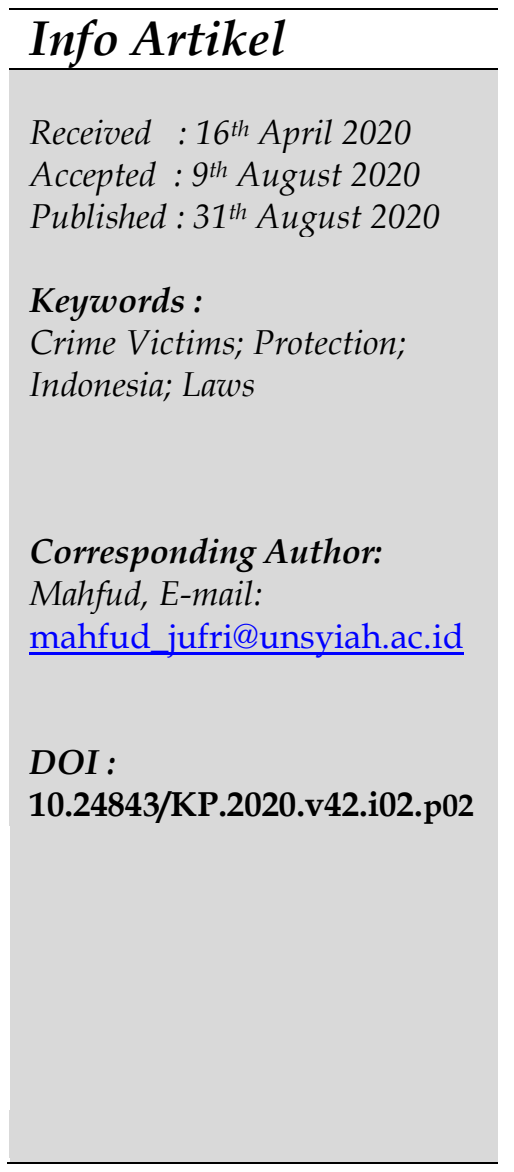

\begin{tabular}{l} 
Abstract \\
The Declaration of Basic Principles of Justice for Victims of \\
Crime and Abuse of Power (1985) ensures the protection of \\
victims of crime. Basically, the implementation of this \\
international declaration depends on the domestic law of each \\
state. Indonesia has promulgated Act No. 13 of 2006 \\
concerning Witness and Victim Protection (Witness and \\
Victim Protection Act) and its Amendment (Act No. 31 of \\
2014) to give protection of the victim, although not fully \\
adopted the principles contained in the declaration. This article \\
aims to analyze the protection of the victims under the recent \\
Indonesian victim protection Acts and to examine to what \\
extent the Acts in line with the declaration. It is a normative \\
legal research that collects sources from libraries, databases, and \\
archives. This research suggested that Witness and Victim \\
Protection Act has provided the protection to the victim that is \\
limited to victims of a grave violation of human rights, \\
terrorism, trafficking, torture, sexual crime, and serious \\
assaults in the form of compensation (only for a grave violation \\
of human rights and terrorism), restitution and certain \\
assistances under the auspices of the Witness and Victim \\
Protection Agency (LPSK). However, this Act is not yet fully in \\
line with the Declaration, particularly with regard to the right \\
of victims to be present in the criminal justice process to express \\
their views when it comes to their personal interests. \\
\hline
\end{tabular}

\section{Introduction}

The United Nations General Assembly Resolution 40/34 adopted the Declaration of Basic Principles of Justice for Victims of Crime and Abuse of Power (hereinafter, the Declaration) on 29 November 1985. ${ }^{1}$ Indonesia has responded to this by the promulgation of Act No. 13 of 2006 concerning Witness and Victim Protection,

1 United Nations. Declaration of Basic Principles of Justice for Victims of Crime and Abuse of Power, retrieved from https://digitallibrary.un.org/record/107889? ln=en\#recordfiles-collapse-header. (accessed on 14 April 2020). 
hereinafter, Witness and Victim Protection Act) which has been amended by Act No.31 of 2014. The response to the legislation has been claimed as a great achievement made by the Government of the Republic of Indonesia in the efforts of protecting victims of crime in Indonesia.

One of the most important issues in Indonesia is the protection of crime victims. Although the law concerning the protection of victims has been legislated, the protection of victims of crime has not been maximally provided in Indonesia, one of the reasons is the lack of implementing the rule. ${ }^{2}$ Additionally, victims are usually used to present before a court as witnesses to support the prosecutors' charges on perpetrators, which is lacking protection and restorations towards them. ${ }^{3}$ There is the fact that victims of crime must be protected because it keeps them secure and free from intimidation and it encourages other victims to report crimes that happened to them to criminal law enforcers bravely. ${ }^{4} \mathrm{M}$. Arief Amrullah has analyzed that the protection of victims of banking crime in Indonesia by concluding that Indonesian criminal law on this issue is still focusing on perpetrators instead of victims. ${ }^{5}$ In addition, Irwan Safaruddin Harahap has looked into the law protection on children as sexual crime victims through the progressive law perspective and concluded that although the protection towards children must be in accordance with the existing laws, in it has not been well implemented yet. ${ }^{6}$ Moreover, I Gede Suryadi and Suatra Putrawan have identified the protection of human trafficking victims as a form of human rights protection. ${ }^{7}$ Previous researches have looked into the protection of victims of crimes in Indonesia and the human rights context. However, it lacks deeper analysis in regard to the latest existing laws of Act No. 31 of 2014 concerning the Amendment Witness and Victim Protection Act and the Government Regulation No. 7 of 2018 concerning the Provisions of Compensation, Restitutions and Assistance for Witnesses and Victims in Indonesia.

The researchers above have looked into the protection of crime victims in Indonesia and concluded that laws relating to the protection of crime victims have not been maximally implemented and these laws focus more on protecting perpetrators than the

2 Wahyuni, S. (2008). Kebijakan Hukum Pidana dalam Memberikan Perlindungan Hukum Terhadap Korban Tindak Pidana Kejahatan dalam Sistem Peradilan Pidana di Indonesia. LAW REFORM, 3(2), 82-100. doi:10.14710/lr.v3i2.729, p. 85.

3 Tatawi, M. L. (2015). Perlindungan Hukum Terhadap Saksi dan Korban (Kajian Undang-Undang No. 31 Tahun 2014). LEX ET SOCIETATIS, 3(7). p.41-49, 41.

4 Wedani, N. P. A. M., \& Dananjaya, N. S. (2015). Perlindungan Korban Tindak Pidana Perkosaan Selama Proses Peradilan Pidana. Kertha Semaya: Journal Ilmu Hukum, 1-5, p.4.

5 Amrullah, M.A. (2002). Politik Hukum Pidana Dalam Perlindungan Korban Kejahatan Ekonomi di Bidang Perbankan. Ius Quia Iustum Law Journal, 9(21), 23-43. doi: 10.20885/iustum.vol9.iss21.art3, p. 40.

6 Harahap, I. S. (2016). Perlindungan Hukum Terhadap Anak Korban Kejahatan Seksual dalam Perspektif Hukum Progresif. Media Hukum, 23(1), 11. 37-47. doi: 10.18196/jmh.2015.0066.37-47, p.46.

7 Suryadi, I. G., \& Putrawan, S. (2014). Perlindungan Korban Kejahatan Perdagangan Manusia Sebagai Wujud Perlindungan Hak Asasi Manusia. Jurnal Hukum Pidana Fakultas Hukum Universitas Udayana, 1(1), 1-5. p.1. 
victims. In addition, most of the researchers above have not looked into the Act No. 31, 2014 and the Declaration. Therefore, it is important to look into the latest laws on the protection of crime victims in Indonesia. This article aims to analyze the protection of victims of crime in the Act No. 13 of 2006 concerning the Protection of Witnesses and Victims that has been amended with the Act No. 31 of 2014 and to examine to which extent the law has been in accordance with the Declaration.

\section{Research Method}

To discuss this issue, this article uses normative legal research method by looking into the recent legislation and by analyzing the secondary sources concerning this issue and articles that are relevant to this paper.

\section{Results And Discussion}

\subsection{The Protection of Victim of Crime in Act No. 13 of 2006 concerning the} Protection of Witness and Victim and Its Amendment

A victim can be defined as someone who physically and spiritually suffers resulting from the other actions seeking for fulfilling self-interests or other reasons that are against the human rights interest of others who suffer it. ${ }^{8}$ Article 1 (2) of the Witness and Victim Protection Act provides that a victim is a person who suffers from physically, mentally and/or lost economically caused by a crime. Article 5(2) of the Witness and Victim Protection Act states that the victims are limited to certain crimes only, namely: corruption, narcotics/psychotropic, terrorism and other crimes causing a victim facing a danger threatening a victim's life. ${ }^{9}$ There are some changes of the Witness and Victim Protection Act with the Act No. 31 of 2014, including the definition of victims in Article 1(3) of the Act No. 31, 2014 has similar wording to Article 1(2) of the Witness and Victim Protection Act. This victim's definition is different from the one provided in the Declaration which includes emotional suffering. ${ }^{10}$ Although the definition of victim is not completely similar to the Declaration, the Declaration has been a considerable impetus to the birth of the legislations on protecting victims of crime at national levels. ${ }^{11}$ It is undeniable that Indonesian's laws on protecting victims of crime are derived from this Declaration.

${ }^{8}$ Elvandari, S., \& Chan, M. L. (2018). A Patient's Legal Protection as a Victim of Sexual Harassment on Medical Services in Indonesia. Jurnal Cita Hukum, 6(2), 235-252. doi:10.15408/jch.v6i2.8684, p.244.

9 Widiastuti, T. W. (2012). Perlindungan Korban (Saksi) sebagai Sarana Menuju Proses Peradilan Pidana yang Jujur dan Adil. Jurnal Wacana Hukum, 10(2), 9-20. doi: http://dx.doi.org/10.33061/1.jwh.2011.10.2.252, p.19.

10 Bambang Widiyantoro. (2019). Declaration of Basic Principles of Justice for Victims of Crime and Abuse of Power Terhadap Perlindungan Korban. Jurnal Ilmiah Hukum DE JURE: Kajian Ilmiah Hukum, 4(1), 1-12. doi: 10.35706/dejure.v4i1.1859 , p. 7.

${ }^{11}$ Kirchengast, T. (2016). Victims' Rights and the Right to Review: A Corollary of the Victim's Pre-Trial Rights to Justice. International Journal for Crime, Justice and Social Democracy, 5(4), 103-115. doi:10.5204/ijcjsd.v5i4.295, p.104. 
The Indonesia legislations on protecting victims of crime are more likely to recognize them as primary victims. It means they must be suffering the direct impact of crime. ${ }^{12}$ Article 6 (1) of the Act No. 31 of 2014 has altered the scope of protected victims in Article 6 of the Witness and Victim Protection Act that only had limited the Witness and Victim Protection Agency (later called as LPSK) to the victims of a grave violation of human rights. The wording of Article 6 (1) of Act No. 31 of 2014 is as follows:

The victims who are entitled to be protected by the Agency of Witness and Victim Protection are the victims of a grave violation of human rights, victims of terrorism, victims of trafficking, victims of torture, victims of sexual crime, victims of serious assaults.

It can be seen that the crime victims' protection in Indonesia is only limited to certain cases above although it is possible to protect victims of serious assaults. ${ }^{13}$ The Act of Witness and Victim Protection 2014 has developed the compensation model for victims of those limited crimes only. ${ }^{14}$ For instance, Act No. 21 of 2007 concerning Human Trafficking Eradication has referred to the Witness and Protection Act 2014 as the implementing legislation in carrying out the protection of victims of trafficking. ${ }^{15}$ In addition, Article 6 (1) of the latest Act provides that the aforementioned protected victims are entitled to medical aid, psychosocial and psychological rehabilitation aids that are in Article 6 (2) of the Act No. 31 of 2014 clearly stipulates that such aids are given by the LPSK.

In implementing the Act No. 31 of 2014, the Government of the Republic of Indonesia has enacted the Government Regulation No. 77 of 2018 concerning the Provisions of Compensation, Restitutions, and Assistance for Witnesses and Victims. Article 1(2) of the Government Regulation has worded a similar definition to the Witness and Victim Protection Act and its Amendment, regarding the definition of a victim. This Government Regulation is an implementing rule of the above Acts, which is hierarchically having a lower level from above, Acts based on the Indonesian legal system. Thus, it is clear that the Witness and Victim Protection Act recognizes not every crime of the victim. This Act has stipulated that the status of the victim according to this law is decided by the Agency of Witness and Victim Protection. ${ }^{16}$

12 Walklate, S. (2016). The metamorphosis of the victim of crime: From crime to culture and the implications for justice. International Journal for Crime, Justice and Social Democracy, 5(4), 4-16. doi:10.5204/ijcjsd.v5i4.280, p.7.

13 Hendradi, T. Securing Protection And Cooperation of Witnesses and Whistle-Blowers, Available from: http://www. unafei. or. jp/english/pdf/PDF_GG4_Seminar/Fourth_GGSeminar_P68-75. Pdf. (accessed on 14 April 2020).

14 Amrani, H. (2018). Reforming the Compensation Model to Victims of Crime in Indonesia. In SHS Web of Conferences (Vol. 54, p. 08005). EDP Sciences, p.4.

15 Eviningrum, S., \& Jamin, M. (2019, October). Developing Human Rights-Based Legal Protection Model on Victims of Child Trafficking in Indonesia. In 3rd International Conference on Globalization of Law and Local Wisdom (ICGLOW 2019). Atlantis Press, p.82.

16 Ibid. 
As there are some weaknesses in the Witness and Victim Protection Act, the Act No. 31, 2014 has made some improvements by amending some essential provisions regarding the protection of victims of crime in the ambit of both the Acts, one of them is Article 7 of the Witness and Victim Protection Act. ${ }^{17}$ Article 7 of the Act No. 31, 2014 states that:

(1) Every victim of a crime against humanity and terrorism besides being entitled to the rights mentioned in Articles 5 and 6 are also having the rights to compensation.

(2) Compensation for the victims of crime against humanity is proposed by victims themselves, their families or counsels to the Human Rights Court through the Witness and Victim Protection Agency (later called as LPSK).

(3) Financial compensation is provided by LPSK based on the court decision having enforceable power.

(4) The provision of the victims of terrorism is based on laws concerning terrorism suppression.

Concerning the victims of the crime rights, pursuant to Article 5(1) of the Act No. 31 of 2014, the rights comprise of:

a. to get individual, family and property protections and freedom from any threat in providing testimony.

b. to participate in the process of choosing and determining kinds of protection and security support.

c. To witness without any pressure.

d. To get a translator if they need it.

e. To be free from jeopardizing questions.

f. To be informed regarding the case progress.

g. To be informed of the court decision.

h. To be informed if the convicted released.

i. To be his identity kept confidentially.

j. To get a new identity.

k. To get a temporary home.

1. To get a new home.

m. To get his transportation fee compensated.

n. To get a free lawyer.

o. To get living cost during the protection period and/or

p. To be accompanied.

Pursuant to Article 1 point 10 of the Act No. 31 of 2014, compensation is a financial return that is granted by the state because the perpetrators are not able to compensate it fully to the victims or their families. Article 7(2) provides that the victims' family or the counsel to the Court of Human Rights through the LPSK requests the compensation for the victims of a grave breach of human rights violation and the amount of the compensation is determined by the Court that is having an enforceable

17 Marasabessy, F. (2016). Restitusi Bagi Korban Tindak Pidana: Sebuah Tawaran Mekanisme Baru. Jurnal Hukum \& Pembangunan, 45(1), 53-75. doi: http://dx.doi.org/10.21143/jhp.vol45.no1.9, p. 59. 
decision. Article 12 of the Government Regulation No. 8, 2018 states that the Court of Human Rights trying the proposal of the compensation may require the statement from victims, family, counsel, LPSK, National Human Rights Commission or other relevant parties. Meanwhile, Article 7(4) legislates that the compensation for the victims of terrorism is referring to the laws concerning terrorism. It can be seen that only the victims of grave violations of human rights and terrorism can only be eligible for compensation under the recent laws of the protection of victims and witnesses. Thus, it can be concluded that compensation can only be availed for those aforementioned victims only. It means that victims of trafficking, victims of torture, victims of sexual crime, victims of serious assaults are not going to enjoy this statefunded payment. Nevertheless, the latest Act has some weaknesses. First, this Act only protects certain kinds of victims meaning that this Act does not apply to universal or general victims of crimes. ${ }^{18}$ Secondly, Article 7 (1) of Act No. 31 of 2014 regulates that only the victims of a grave breach of human rights violation and terrorism are eligible for the compensation.

Meanwhile, Article 7A of the Act No. 31 of 2014 stipulates that the victims of crime are entitled to some restitution, namely restitution for the loss of property and incomes, the loss caused by directly by crime and/or payment for medical and/or psychological budgets, and the crime is determined by LPSK. ${ }^{19}$ Article 1 point 11 of Act No. 31 of 2014 regulates that restitution is a fund return given to victims or their families by the perpetrators or the third parties. In addition, such restitution may be proposed before or after the enforceable court decision through LPSK and if it is proposed by the decision, it must be inserted by the LPSK into the prosecution office charges. But, if it is proposed after the decision, LPSK may propose it to the court. ${ }^{20}$ In case the victims die, the restitution is given to the heirs of the victims. Unlike, the compensation, the restitution under this victims' protection regime are eligible for all victims of crimes within the ambit of this victim's protection legislation.

Based on Article 19 (1) of the Government Regulation No. 7 of 2018, the kinds of restitutions are namely; the restoration of the loss of property or salary, the restitution of direct effects resulted by the crime and the payment of some fund for medical and/or psychological treatments. Article 19 (2) provides that victims, their families, or counsel may bring the application of the restitution.

The protection of victims of crime might be provided at the levels of pre-investigation, investigation, prosecution and or trial based on the initiation of criminal law enforcers, security officials and or the application from the victim themselves. ${ }^{21}$ Crime victims' protection means that in providing information victims are not worried that if the given information would be incriminating them due to it is suspected as fake

18 Fatoni, S. (2014). Urgensitas Perlindungan Saksi dan Korban dalam Mengungkap Kasus Kekerasan dalam Rumah Tangga. Mimbar Hukum-Fakultas Hukum Universitas Gadjah Mada, 26(3), 442-456. doi: https://doi.org/10.22146/jmh.16026, p.450.

19 Marasabessy, F., Op.cit. p.59.

${ }^{20}$ Ibid., p.59.

${ }^{21}$ Natalia, S. (2013). Perlindungan Hukum Terhadap Saksi Dan Korban Oleh Lembaga Perlindungan Saksi Dan Korban (LPSK). Lex Crimen, 2(2). p.58. 
information. ${ }^{22}$ Thus, such worries must be put aside at all levels of Indonesian criminal proceedings involving victims of crime.

Unlike the Act No. 8 of 1981 concerning the Code of Criminal Procedure, Act No. 31 of 2014 has been considered to be a progressive law on protecting the victims of crimes in Indonesia. ${ }^{23}$ Witness and Victim Protection Act and its Amendment have been unprecedentedly introducing the institution tasked with the protection of the crime victims in Indonesia that is the LPSK. Article 12 of the Witness and Victim Protection Act stated that this agency is responsible to protect the crime of victims and to provide aid for them. The agency is an independent institution which is its headquarter in Jakarta and it might be having its representative in other regions if it is needed and it is accountable for the President. ${ }^{24}$ However, it has been deemed that the LPSK itself has not been integrated into the Indonesian Criminal Justice System yet. ${ }^{25}$

In addition, Article 6 (1) of the Act No.31 of 2014 provides that apart from above rights as mentioned in Article 5 (1) of the Act, the victims of the crimes fall under this Act are also granted with medical assistance and psychosocial and psychological rehabilitation assistances. Article 37 (3)(4) of Government Regulation No. 7 of 2018 states that only witnesses and/or victims, their families and a counsel can apply for such aids and its application should be written and stamped addressed to the LPSK. Moreover, Article 42 of the Government Regulation No. 7 of 2018 regulates that the decision of providing the aids is determined by the LPSK and the decision of aids' provision might comprise of the identity of the witness and/or victim, kind of aid, period of aid provision and hospital or health center or place of rehabilitation for them to obtain treatment and medical services. Both the compensation and these kinds of assistance or aids are funded by the budget of the LPSK. The source of the budget for the compensation and the aids are different from the restitution as the last is requesting the perpetrators to pay for the victims by themselves.

There are strengths and weaknesses of crime victims' protection in Indonesia in the Act 2014. The strengths are the provision of protection for personal, family and property security, guaranty from all threats regarding providing witness statements in all stages of criminal proceedings, freedom to choose kinds of protection and asked with a trap questions and informed concerning the proceedings, court decisions, perpetrators' release and right of having victims' identity being secretly kept and living cost till the end of criminal proceedings. ${ }^{26}$ In addition, Act No. 31 of 2014 Act provides the victims restitution and compensation. The victims of crime against humanity and terrorism are entitled to be granted compensation. ${ }^{27}$ Victims, their families or their representatives to the Human Rights Court through LPSK apply the compensation of crime against

22 Tatawi, M. L., Op.cit., p. 44.

${ }^{23}$ Fatoni, S. Op.cit., 447.

24 Ibid.

25 Ibid.

26 Ariyanti, V. (2019). Konsep Perlindungan Korban dalam Sistem Peradilan Pidana Nasional dan Sistem Hukum Pidana Islam. Al-Manahij: Jurnal Kajian Hukum Islam, 13(1), 33-48. doi: https:// doi.org/10.24090/mnh.v0i1.2224 p.38-39.

27 Ali, M., \& Wibowo, A. (2018). Kompensasi dan Restitusi yang Berorientasi pada Korban Tindak Pidana. Yuridika, 33(2), 260-289. doi: 10.20473/ydk.v33i2.7414, p.278. 
humanity and the compensation for terrorism victims can only be provided under the legislations on terrorism. ${ }^{28}$ Moreover, the victims have the right to restitution due to property loss, direct suffering from crime and medical or psychological treatment repayment. However, some weaknesses can be highlighted regarding crime victims' protection in Indonesia. Firstly, this Act is that the Act only protects exclusive victims mentioned in the 2014 Act only based on the decision of the LPSK. ${ }^{29}$ Secondly, compensation is only payable to the victims of crimes against humanity. ${ }^{30}$ Finally, despite the fact that the victims of crimes against humanity are represented by LPSK in seeking the compensation, their participation before the court are only as witnesses because police and prosecution office have taken their rights in a criminal proceeding. ${ }^{31}$

Similar to Indonesia, Malaysia, Hong Kong, Singapore, and Brunei Darussalam also recognize restitution and compensation in protecting victims of crime. The court in these countries might order restitution as a conviction in addition to or instead of the punishment although such decision now is rarely used in those Asian countries as lack of guidance and precedents, failure of the prosecutor to ask this payment, unreasonable trial delay and offender inability to provide that payment. ${ }^{32}$ Unlike in aforementioned Asian countries, Thailand's way in protecting crime victims is done through civil action that is done through the court's civil liability sentence of a defendant either he is acquittal or not, but Thai scholars have challenged this European Continental system of liability by saying that this method is toothless if a defendant is an impecuniosity. ${ }^{33}$

\subsection{To Which Extent the Legislations on Protecting Victims of Crimes in Indonesia Complies with the United Nation Declaration of Basic Principles of Justice for Victims of Crime and Abuse of Power}

The United Nations Declaration of Basic Principles of Justice for Victims of Crime and Abuse of Power is known as a Magna Charta for victims. ${ }^{34}$ The United Nations adopted this Declaration on 27 December 1985 based on the Seventh United Nations Congress recommendation concerning the Prevention of Crime and the Treatment of

28 Ibid.

${ }^{29}$ Ariyanti, V., Op.cit., 39.

30 Rahmi, A. (2019). Pemenuhan Restitusi Dan Kompensasi Sebagai Bentuk Perlindungan Bagi Korban Kejahatan Seksual Dalam Sistem Hukum Di Indonesia. DE LEGA LATA: Jurnal Ilmu Hukum, 4(2), 140-159. doi: https://doi.org/10.30596/dll.v4i2.3173, p.155.

31 Ibid.

32 Ota, T. (2007). The development of victim support and victim rights in Asia. In Support for Victims of Crime in Asia, 2. New York: Routledge Taylor \& Francis Group, p.116.

33 Ibid.

34 Melup, I. (2018). The United Nations Declaration of Basic Principles of Justice for Victims of Crime and Abuse of Power. The Universal Declaration of Human Rights: Fifty Years and Beyond. Retrieved from https:/ / books.google.co.id/books?hl=en\&lr=\&id=mi1zDwAAQBAJ\&oi=fnd\&pg=P T83\&dq=melup\&ots=_nduNBpCyt\&sig=hx18JIzGdX1eaFGMOWFnILsowc\&redir_esc=y\#v=onepage\&q=melup\&f=false. (accessed on 2 August 2020) 
Offenders on 26 August - 6 September 1985 in Milan. ${ }^{35}$ It has been claimed as one of the most substantial developments made by the UN General Assembly. ${ }^{36}$

It emphasizes on formulating norms' series of guideline made to boost more humane and to empower domestic policies and more effective cooperation globally in this issue. ${ }^{37}$ It is a substantial achievement, initiating in its field considered to be fair, sensitive and suitable treatment for victims, service access, and legal basis and put thing right of basic justice. ${ }^{38}$ The Declaration has played a pivotal role in repairing the equality between the basic rights of perpetrators and the victims' interests. ${ }^{39}$ It defines a victim as a person who, individually or collectively, has suffered harm, either physical or mental injury, emotional suffering, financial loss or substantial damage of their fundamental rights either intentionally or negligence violating criminal laws applied in the Member States, including the laws which proscribe criminal power abuse. ${ }^{40}$ The aforementioned definition of the victim has divided victims into two types that are victims of crime and victims of certain power abuses. ${ }^{41}$ It means that the Declaration is not only protecting victims of crimes but also it is protecting victims of power abuses. ${ }^{42}$ Besides introducing such two types of victims' definition, it is also introducing the abuse power concept as an infringement of international norms concerning human rights and prohibiting discrimination in treating victims. ${ }^{43}$ Defining the definition of a victim might be difficult as each law governing a victim has different ways of defining the term. Generally, someone who suffers either physical or mental is also called as a victim. ${ }^{4}$ The Declaration defines the victims as a person who is unfairly subjected to loss, damage or injury resulting from the crime. Meanwhile, the latest law on protecting victims of crime in Indonesia defines it as a person suffers physically,

35 Ibid.

${ }^{36}$ Fattah, E. A. (2013). From crime policy to victim policy: The need for a fundamental policy change. Victims of crime and the victimization process, p.75.

37 Melup, I., Op.cit.

38 Ibid.

39 Asli, M. R. (2006). Iranian criminal justice system in light of international standards relating to victims. European Journal of Crime, Criminal Law and Criminal Justice, 14(2), 185-207. doi: https://doi.org/10.1163/157181706777978748, p.186.

40 Ibid., 188.

${ }^{41}$ Aldana-Pindell, R. (2004). An Emerging Universality of Justiciable Victims' Rights in the Criminal Process to Curtail Impunity for State-Sponsored Crimes. Human Rights Quarterly, 26(3), 605-686. p.652.

42 Harkrisnowo, H. (2007). Victims: the forgotten stakeholders of the Indonesian criminal justice system. Support for victims of crime in Asia, 2, New York: Routledge Taylor \& Francis Group, p.262.

43 Buczma, S. R. (2013, September). An overview of the law concerning protection of victims of crime in the view of the adoption of the Directive 2012/29/EU establishing minimum standards on the rights, support, and protection of victims of crime in the European Union. In ERA Forum (Vol. 14, No. 2, pp. 235-250). Springer Berlin Heidelberg, p.236.

44 Mahfud, M. (2014). Extra-Territorial Torture and Inhuman Treatment towards Suspected Terrorists Committed By the UK and the US Military Actions. Indonesian Journal of International Law, 11(2), 218-260. doi: http://dx.doi.org/10.17304/ijil.vol11.2.277, p.223. 
mentally and/or economically loss resulting from the crime. The latest law regulating the definition of the victims of crime in Indonesia has been in line with the Declaration.

Before the promulgation of the Witness and Victim Protection Act and its Amendment in Indonesia, there was no protection granted upon them. ${ }^{45}$ Thus, it can be said that the laws are unprecedented norms in Indonesia dealing with the protection of victims of crime recently. The Declaration has introduced the duty of a state to provide a remedy for a victim of crime. ${ }^{46}$ It is stipulated in Article 4 (a) of the Declaration which requires the Member States to make some efforts in complying to the Declaration aiming at preventing victimization from happening by implementing policies reducing victimization either social, health, education, economy and special crime prevention and encouraging aids to critical victims. ${ }^{47}$ In addition, the Article $4(\mathrm{~h})$ also requires the contracting states to cooperate with other nations through reciprocal judicial and administrative aids concerning to detect, to find of perpetrators, to extradite, and to seize their assets in order to be used for victim restitution. 48

The main component provisions concerning the victims' protection in the Declarations are as follows: 49

a. There should be mechanism-enabling victims to obtain redress through formal or informal processes that are expeditious, fair, cheap and accessible.

b. Victims should be allowed to represent their views and concerns and these should be considered at appropriate levels of the processes, which their interests are influenced.

c. Victims are assisted during the processes.

d. To take measures to reduce inconvenience and to protect their privacy and ensure they are not intimidated and retaliated.

e. To avoid any delay of the procedures.

f. To provide their material needs and aids of medical, psychology, and social conducted by government, volunteers, community and locals.

g. Training should be provided for criminal law agencies in order to sensitize the victim's needs and guidance to make sure appropriate and prompt assistance.

h. Vulnerable victims should have special attention regarding the provisions of services and assistance.

45 Bey, F. (2004). The Implementation of Declaration of Basic Principles of Justice for Victims of Crime and Abuse of Power in Indonesia, A Comparative Study. Lex Jurnalica, 2(1), p.26.

${ }^{46}$ Bassiouni, M. C. (2006). International Recognition of Victims' Rights. Human Rights Law Review, 6(2), 203-279, doi: https://doi.org/10.1093/hrlr/ngl009, p. 216.

47 Crawshaw, R., \& Holmström, L. (2008). 11. Declaration of Basic Principles of Justice for Victims of Crime and Abuse of Power. In Essential Texts on Human Rights for the Police (pp. 489-495). Brill Nijhoff., p. 490.

48 Ibid.

49 Van Genugten, W., Van Gestel, R., Groenhuijsen, M., \& Letschert, R. (2006). Loopholes, risks and ambivalences in international lawmaking: the case of a framework convention on victims' rights. Netherlands Yearbook of International Law, 37, 109-154. doi: https:// doi.org/10.1017/S0167676806001097, p.116. 
In terms of reviewing whether the Witness and Victim Protection Act and its Amendment has complied with the Declaration, this article will use the above main provision components of the Declaration as the benchmarks. Firstly, concerning the mechanisms that can be used by the victims in obtaining the remedy, both the Indonesian Acts of Witness and Victim Protection have incorporated the mechanisms for obtaining the remedy. Rights to justice access and fair treatment for the victims of crime are very essential under the Declaration. ${ }^{50}$ By the mechanism provided under these Acts, it is expected that the victims can afford the rights above. Before the enactment of the latest Act No. 31 of 2014, the remedy mechanism for restitution towards Witness and Victim has been incorporated in the Witness and Victim Protection Act and the Government Regulation No. 44 of 2008. ${ }^{51}$ The application for restitution is done through the penal court decision and later the convicted pay for the compensation. ${ }^{52}$ It is clearly stated in Article 7A (4) of the Act No. 31 of 2014 that the restitution application is submitted before the court decision is enforceable, and it is also possible that the restitution application is made by the LPSK through the public prosecution office in order to be inserted in the charge of the prosecution. ${ }^{53}$ Thus, it means that the application is done through two institution-the LPSK and the Public Prosecution Office. In addition, Chapter 2 of the Government Regulation No. 7 of 2018 has provided a clear mechanism for applying the compensation for the victims of a grave breach of human right violation and restitution for the victims of crime under the ambit of Article 6(1) of the Act No. 31 of 2014.

Nevertheless, regarding the right to represent their views and concerns which their personal interests are influenced at criminal proceedings ha not been accommodated yet in both of the Indonesian's Witness and Victim Protection Acts. Article 5(1) of the Act No.31, 2014 has not ruled on the right of the victims to represent their views and concerns that their personal interests are influenced yet. It is different from what the role of the victim before the International Criminal Court trial has that a victim may be participating in the proceeding if a victim has a personal interest. ${ }^{54}$ Article 6(b) of the Declaration has clearly stated that if their personal interest is influenced, they are allowed to present their views and concerns. .5

50 Yulia, R. (2016). Menggugat Pemenuhan Hak Korban Pelanggaran Hak Asasi Manusia Masa Lalu. Jurnal Hukum PRIORIS, 4(3), 266-278, 268.

51 Suhariyanto, B. (2013). Quo Vadis Perlindungan Hukum Terhadap Korban Melalui Restitusi (Perspektif Filsafat, Teori, Norma dan Praktek Penerapannya). Jurnal Hukum dan Peradilan, 109-130. doi:http://dx.doi.org/10.25216/JHP.2.1.2013.109-130, p.111.

52 Bimantara, I., \& Sumadi, I.(2018). Konsep Restitusi Terhadap Perlindungan Korban Tindak Pidana Di Indonesia. Kertha Wicara: Journal Ilmu Hukum, 1-5. p.3.

53 Ibid., p. 12.

54 Jufri, M. (2019). The Roles of Victims in the ICC: Victims' Protection or the Accused's Fair Trial Right Violation?. Hasanuddin Law Review, 5(1), 28-40. doi: http://dx.doi.org/10.20956/halrev.v5i1.1423, p.30.

55 Fattah, E. A. (1992). The United Nations declaration of basic principles of justice for victims of crime and abuse of power: A constructive critique. In Towards a critical victimology (pp. 401-424). London: Palgrave Macmillan, p.409. 
The Declaration is also requiring the member states to provide restitution, compensation, and assistance for the victims. ${ }^{56}$ In relation to the material needs of the victims, the Acts have incorporated the restitution and compensation for the victims within the ambit of these Acts. Although the Act No. 31, 2014 has introduced restitution to protect the victims, it still has weaknesses that the LPSK does not accept all restitution application to be submitted to the court meaning that the application might be rejected and if the restitution granted by the court, the LPSK is not entitled to execute it because it has no execution power over the court decision. ${ }^{57}$ In addition, pursuant to Article 7(2) of Act No. 31, 2014, the compensation worded under this Act is limited to the victims of a grave violation of human rights cases. Meanwhile, compensation for the victims of terrorism falls under the laws governing terrorism. Moreover, concerning the assistance provided for the victims during the processes, Article 1 (8) of the Act No. 31, 2014 has regulated that the LPSK is assigned to assist victims of the crimes under the Acts. Both restitution and compensation applications are submitted to the court trough the LPSK. ${ }^{58}$ Furthermore, Article 5 (o) and (p) also states that they are entitled to the living cost during the protection period and is accompanied by the LPSK. According to this Act, this duty and power belong to the body and other referred institution.59 The fulfillment of the rights and assistance is aiming to comfort the victims. ${ }^{60}$ This assistance would be essential especially for the victims of the grave breach of human rights. ${ }^{61}$

The privacy of victims has been the main concern of the Act on Witness and Victim Protection in Indonesia. Article 5 of the Witness and Victim Protection Act and has ruled that if it is necessary, victims might be placed in a secret place which not known by anyone purposing at ensuring they are safe. ${ }^{62}$ In addition, after the amendment, Article 5 (i) has emphasized that the identities of victims must be kept confidential. Besides Article 5 (i), Article 12A (f) provides the victims safe homes which means a new home or a temporary home that is kept secretly based on the standards made by the LPSK. Government Regulation No. 7 of 2018 has not made any additional references for this matter. It would be better if this Regulation has clarity on the efforts of keeping the privacy of the victims either their identities or addresses.

56 Yulia, R., Op.cit., 269.

57 Wijaya, I. A., \& Purwadi, H. (2018). Pemberian Restitusi sebagai Perlindungan Hukum Korban Tindak Pidana. Jurnal Hukum Dan Pembangunan Ekonomi, 6(2). Retrieved from https://jurnal.uns.ac.id/hpe/article/view/17728, p.103. (accesed on 3 August 2020)

58 Pratama, A. (2016). Perbandingan Perlindungan Terhadap Saksi dan Korban Kejahatan di Indonesia dan New Zealand. ETD Unsyiah. Retrieved from https://etd.unsyiah.ac.id/baca/index.php?id=22949\&page=2, p.2. (accesed on 4 August 2020).

59 Komariah, M. (2015). Perlindungan Hukum Saksi Dan Korban Oleh Lembaga Perlindungan Saksi dan Korban (LPSK). Jurnal Ilmiah Galuh Justisi, 3(2), 229-244, p.231.

60 Ibid., p. 233.

61 Samendawai, A. H. (2009). Hak-Hak Korban Pelanggaran HAM Yang Berat (Tinjauan Hukum Internasional dan Nasional). Jurnal Hukum Ius Quia Iustum, 16(2), 253-267. doi: 10.20885/iustum.vol16.iss2.art6, p.256.

62 Ibid., p. 260. 
The norm to avoid delaying the application for victims' protection has also been found in Act No. 31 of 2014. Article 29 (b) of the Act has regulated that the LPSK obliges to check documents for the application for protecting the victims immediately, and the decision must be made within 7 (seven) days. ${ }^{63}$ Some comments on this period that it is considered to be relatively long for waiting for the decision and it will still a potential threat towards the victims before the LPSK decided if their applications admitted or not. 64

The Declaration demands that Indonesia should also have the provisions on providing material needs and aids of medical, psychological, and social of victims of crime conducted by the government, volunteers, community and locals in the country legislations on protecting the victims of crime. The Acts have incorporated sorts of aids that are provided towards the victims that can be seen in Articles 1(8) and 5(1) of the amended Act that the victims of the crime fall under this Act are eligible to medical, psychosocial and psychological rehabilitation assistances. It is then stressed in Article 37 (3)(4) of the Government Regulation No. 7 of 2018 granting the victims, their families, or counsel to apply for the aids. This aids only limited to medical, psychosocial and psychological rehabilitation assistance. ${ }^{65}$ However, the aids can only be provided by LPSK as the government agency dealing with the task meaning that volunteers, community and locals are not allowed to provide such assistance.

Additionally, the Witness and Victim Protection Act and its Amendment have not regulated a specific category of vulnerable victims into the Acts. To comply with the Declaration's request in providing special attention towards vulnerable victims of crime relating to the provisions of services and assistance, Witness and Victim Protection Act and its Amendment only group victims based on the kinds of the perpetrations or crimes committed namely; a grave violation of human rights, terrorism, trafficking, torture, sexual crime, and serious assaults. It seems that both the laws have considered all the victims of the aforementioned crimes are vulnerable. Thus, there is no point in making a new category of vulnerable victims in these Acts.

To increase Indonesia criminal law agencies dealing with the protection of the victims of crime including the LPSK are essential. It is as required by Article 5 (a) of the Declaration which recommends that member states should take all appropriate measures in terms of promoting training activities aiming at fostering compliance with the standards of the United Nations in protecting victims.66 In relation to the Declaration request that the member states should train criminal law agencies regarding understanding the victim's needs and being able to provide appropriate and

63 Sabrina, N. (2016). Perlindungan dan Pemenuhan Hak Korban Tindak Pidana Dalam Sistem Peradilan Pidana. Jurnal Cakrawala Hukum, 7(2), 229-237. p.233.

64 Ibid.

65 Bawinto, E. (2016). Perlindungan Hukum Bagi Perempuan Korban Kejahatan Penyiksaan Berdasarkan Undang-Undang Nomor 31 Tahun 2014. Lex Et Societatis, 4(2.1), 39-46. p.43

66 Refworld. Declaration of Basic Principles of Justice for Victims of Crime and Abuse of Power: resolution/adopted by the General Assembly. Available from https://www.refworld.org/docid/3b00f2275b.html. (accesed on 14 April 2020). 
prompt assistance, but both the Acts do not regulate what kind of training that is provided for them. It might be that the training has been done by each criminal law agency before appointing its staff to deal with the victims of the crime protection issue. The question to which extent the trainees from each criminal law agency being professionally capable in providing maximal protection towards the victims is potential further research to be conducted. It needs further studies on the issue. Nevertheless, at least, the Act No. 31 of 2014, in its explanation part has mentioned that there is a need to empower the agencies and the LPSK in complying with the Declaration

\section{Conclusion}

Act No. 13 of 2006 concerning Witness and Victim Protection Act and its Amendment (Act No. 31 of 2014) have provided the protection that is limited to victims of a grave violation of human rights, terrorism, trafficking, torture, sexual crime, and serious assaults in the form of compensation (only for a grave violation of human rights and terrorism), restitution and certain assistances under the auspices of the Witness and Victim Protection Agency (LPSK). These Acts have not yet complied with the Declaration in terms of providing the right to represent their views and concerns which their interests are influenced at criminal proceedings ha not been accommodated yet in both of the Indonesian's Witness and Victim Protection Acts and the involvement of communities and volunteers is not allowed in providing such assistance. The implementation of the recent Indonesian Acts dealing with the protection of victims of crime would be better if the LPSK, as the only agency assisting the victims of the crimes within the ambit of these victims' protection Acts, decide the application of the victims' protection below 7 (seven) working days. Thus, the victims need not wait longer and the protection can be available earlier

\section{REFERENCES}

\section{Books}

Crawshaw, R., \& Holmström, L. (2008). 11. Declaration of Basic Principles of Justice for Victims of Crime and Abuse of Power. In Essential Texts on Human Rights for the Police. Brill Nijhoff, pp. 489-495.

Fattah, E. A. (2013). From crime policy to victim policy: The need for a fundamental policy change. Victims of crime and the victimization process.

Fattah, E. A. (1992). The United Nations declaration of basic principles of justice for victims of crime and abuse of power: A constructive critique. In Towards a critical victimology (pp. 401-424). London: Palgrave Macmillan.

Harkrisnowo, H. (2007). Victims: the forgotten stakeholders of the Indonesian criminal justice system. Support for victims of crime in Asia, 2, New York: Routledge Taylor \& Francis Group.

Ota, T. (2007). The development of victim support and victim rights in Asia. In Support for Victims of Crime in Asia, 2. New York: Routledge Taylor \& Francis Group.

\section{Journals}


Aldana-Pindell, R. (2004). An Emerging Universality of Justiciable Victims' Rights in the Criminal Process to Curtail Impunity for State-Sponsored Crimes. Human Rights Quarterly, 26(3), 605-686.

Ali, M., \& Wibowo, A. (2018). Kompensasi dan Restitusi yang Berorientasi pada Korban Tindak Pidana. Yuridika, 33(2), 260-289. doi: 10.20473/ydk.v33i2.7414.

Amrullah, M.A. (2002). Politik Hukum Pidana Dalam Perlindungan Korban Kejahatan Ekonomi di Bidang Perbankan. Ius Quia Iustum Law Journal, 9(21), 23-43. doi: 10.20885/iustum.vol9.iss21.art3.

Ariyanti, V. (2019). Konsep Perlindungan Korban dalam Sistem Peradilan Pidana Nasional dan Sistem Hukum Pidana Islam. Al-Manahij: Jurnal Kajian Hukum Islam, 13(1), 33-48. doi: https:// doi.org/10.24090/mnh.v0i1.2224.

Asli, M. R. (2006). Iranian criminal justice system in light of international standards relating to victims. European Journal of Crime, Criminal Law and Criminal Justice, 14(2), 185-207. doi: https:/ / doi.org/10.1163/157181706777978748.

Bambang Widiyantoro. (2019). Declaration of Basic Principles of Justice for Victims of Crime and Abuse of Power Terhadap Perlindungan Korban. Jurnal Ilmiah Hukum DE JURE: Kajian Ilmiah Hukum, 4(1), 1-12. doi: 10.35706/dejure.v4i1.1859.

Bassiouni, M. C. (2006). International Recognition of Victims' Rights. Human Rights Law Review, 6(2), 203-279, doi: https://doi.org/10.1093/hrlr/ngl009.

Bawinto, E. (2016). Perlindungan Hukum Bagi Perempuan Korban Kejahatan Penyiksaan Berdasarkan Undang-Undang Nomor 31 Tahun 2014. Lex Et Societatis, 4(2.1), 39-46.

Buczma, S. R. (2013, September). An overview of the law concerning protection of victims of crime in the view of the adoption of the Directive 2012/29/EU establishing minimum standards on the rights, support and protection of victims of crime in the European Union. In ERA Forum (Vol. 14, No. 2, pp. 235-250). Springer Berlin Heidelberg.

Bey, F. (2004). The Implementation of Declaration of Basic Principles of Justice for Victims of Crime and Abuse of Power in Indonesia, A Comparative Study. Lex Jurnalica, 2(1).

Bimantara, I., \& Sumadi, I.(2018). Konsep Restitusi Terhadap Perlindungan Korban Tindak Pidana Di Indonesia. Kertha Wicara: Journal Ilmu Hukum, 1-5.

Elvandari, S., \& Chan, M. L. (2018). A Patient's Legal Protection as a Victim of Sexual Harassment on Medical Services in Indonesia. Jurnal Cita Hukum, 6(2), 235-252. doi:10.15408/jch.v6i2.8684.

Fatoni, S. (2014). Urgensitas Perlindungan Saksi dan Korban dalam Mengungkap Kasus Kekerasan dalam Rumah Tangga. Mimbar Hukum-Fakultas Hukum Universitas Gadjah Mada, 26(3), 442-456. doi: https://doi.org/10.22146/jmh.16026.

Harahap, I. S. (2016). Perlindungan Hukum Terhadap Anak Korban Kejahatan Seksual dalam Perspektif Hukum Progresif. Media Hukum, 23(1), 11. 37-47. doi: 10.18196/jmh.2015.0066.

Jufri, M. (2019). The Roles of Victims in the ICC: Victims' Protection or the Accused's Fair Trial Right Violation?. Hasanuddin Law Review, 5(1), 28-40. doi: http://dx.doi.org/10.20956/halrev.v5i1.1423.

Kirchengast, T. (2016). Victims' Rights and the Right to Review: A Corollary of the Victim's Pre-Trial Rights to Justice. International Journal for Crime, Justice and Social Democracy, 5(4), 103-115. doi:10.5204/ijcjsd.v5i4.295.

Komariah, M. (2015). Perlindungan Hukum Saksi Dan Korban Oleh Lembaga Perlindungan Saksi dan Korban (LPSK). Jurnal Ilmiah Galuh Justisi, 3(2), 229-244. 
Mahfud, M. (2014). Extra-Territorial Torture and Inhuman Treatment towards Suspected Terrorists Committed By the UK and the US Military Actions. Indonesian Journal of International Law, 11(2), 218-260. doi: http://dx.doi.org/10.17304/ijil.vol11.2.277.

Marasabessy, F. (2016). Restitusi Bagi Korban Tindak Pidana: Sebuah Tawaran Mekanisme Baru. Jurnal Hukum \& Pembangunan, 45(1), 53-75. doi: http://dx.doi.org/10.21143/ihp.vol45.no1.9.

Natalia, S. (2013). Perlindungan Hukum Terhadap Saksi Dan Korban Oleh Lembaga Perlindungan Saksi Dan Korban (LPSK). Lex Crimen, 2(2).

Rahmi, A. (2019). Pemenuhan Restitusi Dan Kompensasi Sebagai Bentuk Perlindungan Bagi Korban Kejahatan Seksual Dalam Sistem Hukum Di Indonesia. DE LEGA LATA: Jurnal Ilmu Hukum, 4(2), 140-159. doi: https:// doi.org/10.30596/dll.v4i2.3173.

Sabrina, N. (2016). Perlindungan dan Pemenuhan Hak Korban Tindak Pidana Dalam Sistem Peradilan Pidana. Jurnal Cakrawala Hukum, 7(2), 229-237.

Samendawai, A. H. (2009). Hak-Hak Korban Pelanggaran HAM Yang Berat (Tinjauan Hukum Internasional dan Nasional). Jurnal Hukum Ius Quia Iustum, 16(2), 253267. doi: $10.20885 /$ iustum.vol16.iss2.art6.

Suhariyanto, B. (2013). Quo Vadis Perlindungan Hukum Terhadap Korban Melalui Restitusi (Perspektif Filsafat, Teori, Norma dan Praktek Penerapannya). Jurnal Hukum dan Peradilan, 2(1), 109-130. doi: http://dx.doi.org/10.25216/JHP.2.1.2013.109-130.

Suryadi, I. G., \& Putrawan, S. (2014). Perlindungan Korban Kejahatan Perdagangan Manusia Sebagai Wujud Perlindungan Hak Asasi Manusia. Jurnal Hukum Pidana Fakultas Hukum Universitas Udayana, 1(1), 1-5.

Tatawi, M. L. (2015). Perlindungan Hukum Terhadap Saksi dan Korban (Kajian Undang-Undang No. 31 Tahun 2014). LEX ET SOCIETATIS, 3(7). 41-49.

Van Genugten, W., Van Gestel, R., Groenhuijsen, M., \& Letschert, R. (2006). Loopholes, risks and ambivalences in international lawmaking: the case of a framework convention on victims' rights. Netherlands Yearbook of International Law, 37, 109154. doi: https:// doi.org/10.1017/S0167676806001097.

Wahyuni, S. (2008). Kebijakan Hukum Pidana dalam Memberikan Perlindungan Hukum Terhadap Korban Tindak Pidana Kejahatan dalam Sistem Peradilan Pidana di Indonesia. LAW REFORM, 3(2), 82-100. doi:10.14710/lr.v3i2.729.

Walklate, S. (2016). The metamorphosis of the victim of crime: From crime to culture and the implications for justice. International Journal for Crime, Justice and Social Democracy, 5(4), 4-16. doi:10.5204/ijcjsd.v5i4.280.

Wedani, N. P. A. M., \& Dananjaya, N. S. (2015). Perlindungan Korban Tindak Pidana Perkosaan Selama Proses Peradilan Pidana. Kertha Semaya: Journal Ilmu Hukum, $1-5$.

Widiastuti, T. W. (2012). Perlindungan Korban (Saksi) sebagai Sarana Menuju Proses Peradilan Pidana yang Jujur dan Adil. Jurnal Wacana Hukum, 10(2), 9-20. doi: http://dx.doi.org/10.33061/1.jwh.2011.10.2.252.

Wijaya, I. A., \& Purwadi, H. (2018). Pemberian Restitusi sebagai Perlindungan Hukum Korban Tindak Pidana. Jurnal Hukum Dan Pembangunan Ekonomi, 6(2).

Yulia, R. (2016). Menggugat Pemenuhan Hak Korban Pelanggaran Hak Asasi Manusia Masa Lalu. Jurnal Hukum PRIORIS, 4(3), 266-278. 
Thesis

Pratama, A. (2016). Perbandingan Perlindungan Terhadap Saksi dan Korban Kejahatan di Indonesia dan New Zealand. ETD Unsyiah. Retrieved from https://etd.unsyiah.ac.id/baca/index.php?id=22949\&page=2, p.2. (accesed on 4 August 2020).

\section{Proceedings}

Amrani, H. (2018). Reforming the Compensation Model to Victims of Crime in Indonesia. In SHS Web of Conferences (Vol. 54, p. 08005). EDP Sciences.

Eviningrum, S., \& Jamin, M. (2019, October). Developing Human Rights-Based Legal Protection Model on Victims of Child Trafficking in Indonesia. In 3rd International Conference on Globalization of Law and Local Wisdom (ICGLOW 2019). Atlantis Press.

\section{Law and Regulations of the Republic of Indonesia}

Act No. 8 of 1981 concerning the Code of Criminal Procedure Act No. 13 of 2006 concerning Witness and Victim Protection

Act No. 21 of 2007 concerning Human Trafficking Eradication

Act No. 31 of 2014 concerning the Amendment of Act No. 13 of 2006 concerning Witness and Victim Protection

Government Regulation No. 7 of 2018 concerning the Provisions of Compensation, Restitutions, and Assistance for Witnesses and Victims.

\section{International Instrument}

Declaration of Basic Principles of Justice for Victims of Crime and Abuse of Power

\section{Websites}

Hendradi, T. Securing Protection And Cooperation of Witnesses and Whistle-Blowers, Available from: http://www. unafei. or. jp/english/pdf/PDF_GG4_Seminar/Fourth_GGSeminar_P68-75. Pdf. (accessed on 14 April 2020).

Melup, I. (2018). The United Nations Declaration of Basic Principles of Justice for Victims of Crime and Abuse of Power. The Universal Declaration of Human Rights: Fifty Years and Beyond. Retrieved from https:// books.google.co.id/books?hl=en\&lr=\&id=mi1zDwAAQBAJ\&oi=fnd\&pg $=$ PT83\&dq=melup\&ots $=\_$nduNBpCyt\&sig=hx18JIzGdX1eaFGMOWFnILsowc\&redir_esc $=\mathrm{y} \# \mathrm{v}=$ onepage\& $\mathrm{q}=$ melup\&f $=$ false. (accessed on 2 August 2020).

Refworld. Declaration of Basic Principles of Justice for Victims of Crime and Abuse of Power: resolution/adopted by the General Assembly. Available from https:// www.refworld.org/docid/3b00f2275b.html. (accesed on 14 April 2020).

United Nations. Declaration of Basic Principles of Justice for Victims of Crime and Abuse of Power, retrieved from https:// digitallibrary.un.org/ record/107889?ln=en\#record-files-collapse-header. (accessed on 14 April 2020). 